\title{
Canada and the World Glacier Inventory
}

\author{
C. Simon L. OMMANNEY \\ 56 Spinney Road, PO Box 730, R.R. \#1, Glenwood, Yarmouth County, Nova Scotia BOW 1W0, Canada \\ E-mail: simon.ommanney@ns.sympatico.ca
}

\begin{abstract}
This paper reviews the origins of the World Glacier Inventory program and Canada's participation. It tracks the program of the Canadian federal government from its initiation to its demise. Today, progress is geared towards the international GLIMS and GlobGlacier programs, to which scientists from several Canadian universities are making contributions. Achievements during the past decade, towards providing data on Canada's glacierized areas in the Arctic and in western Canada, are documented.
\end{abstract}

\section{INTRODUCTION}

Canada was one of the countries that made a strong commitment to contribute to the World Glacier Inventory (WGI) for the International Hydrological Decade (IHD; 1970s). This followed an earlier inventory started at the University of Toronto for the International Geophysical Year (IGY; 1957/ 58). Recommendations were drawn up and tested at McGill University in the mid-1960s, before work on the complete inventory began with the establishment of a Glacier Inventory Section by the federal government in 1968. Initial work was carried out in Ottawa before relocation led to the transfer of the group to Saskatoon in 1986. The involvement of the government in the WGI ended with the departure of the principal investigator in 1993. Since that time, higherresolution satellite images and vastly improved analytical techniques mean that the options for compiling information on glaciers have changed, rendering many of those applied to the early inventory obsolete. New programs and resources are ensuring that information on Canada's glacierized areas is being compiled. Cogley (2009) has highlighted the need to identify all regional inventories and undertake the rescue and assimilation of them. Outlined below are the various elements of the original Canadian inventory program and subsequent work that identifies what was done and may help further extend Canada's glacier inventory.

\section{THE IGY AND THE FIRST CANADIAN GLACIER INVENTORY}

The first Canadian glacier inventory was initiated in response to an IGY resolution, first proposed in 1955, by the Comité Spécial de I'Année Géophysique Internationale (CSAGI) (IUGG, 1956), for countries to undertake a census of their glaciers. The specific recommendations for this inventory were published in 1959 (Annals of the IGY, 1959). They called for much the same data as were included in the subsequent IHD inventory. The work was undertaken at the University of Toronto, but never published (Falconer and others, 1958). A set of the data and maps are on file at the National Hydrology Research Centre (NHRC) in Saskatoon. Falconer later used some of the work as the basis for a report on the glaciers of northern Baffin and Bylot Islands (Falconer, 1962).

\section{THE IHD GLACIER INVENTORY}

In 1964, at the IHD Intergovernmental Meeting of Experts, a proposal was put forward for national inventories of perennial and annual snow and ice masses (UNESCO, 1964). Canada had agreed to active participation in the IHD, and an inventory of glaciers became part of the formal Canadian program that same year, under George Falconer of the Geographical Branch, Department of Energy, Mines and Resources. In the first work completed, the glacierized areas of Canada were delineated on the best scale of maps available and used as the basis for a series of seven glacier maps of Canada at a scale of 1:1000000 (Ommanney, 2002, table 1, p. J84). W.E.S. Henoch then used these maps to determine an area of $151436 \mathrm{~km}^{2}$ for the glaciers of the Canadian Arctic and of $50041 \mathrm{~km}^{2}$ for the mainland (Ommanney, 1971, table 2, p. 29).

In 1966, the Co-ordinating Council for the IHD passed a resolution (I-12, partial) reiterating the need for a detailed inventory, and the International Commission on Snow and Ice (ICSI) established a Working Group, under the chairmanship of Fritz Müller of McGill University, to produce guidelines for a world inventory of perennial snow and ice masses on and beneath the land surfaces.

\section{MCGILL UNIVERSITY AND THE START OF THE CANADIAN IHD INVENTORY}

In the 40 years that have passed since the original guidelines were proposed, there have been major advances in imaging glaciers, specifically through remote-sensing satellites. New technologies such as geographical information systems (GIS) and digital terrain models (DTMs) are now used routinely. Thus the approach to processing spatial data is now very different. In considering where we should be going with glacier inventory, it is relevant to reflect on where we came from. The author was instrumental in developing and testing the guidelines that were submitted to the Working Group for approval.

In the mid-1960s, there were a number of aspects to be considered in developing guidelines for an inventory: an identification system; a classification system; the basic dataset and the source materials from which these data would be compiled; and the separation between the ice features on and below the land surface.

\section{Identification system}

As the focus of the IHD was on the world's water resources, any identification system adopted ought to relate to hydrological basins. For mainland Canada, the Water Survey of Canada (WSC) basin system was used. For Arctic Canada, 
where basins had not yet been identified, it was decided to use numbers based on the cataloguing system of the Scott Polar Research Institute, UK (Roberts, 1963). A UDCPL prefix (see Roberts, 1963) was added to the WSC basin identifier; subsequently, new identifiers were determined for each basin under a global subdivision proposed by the Temporary Technical Secretariat for the World Glacier Inventory (Ommanney, 1978). Within each hydrological basin, glaciers would be delineated and numbered sequentially and a coordinate selected two-thirds of the distance between the snout and the snowline along the main flowline. For assessing sea-level change, there might now be an argument to be made for using glaciological units such as icefields and ice caps.

\section{Classification system}

It was considered desirable to be able to describe the main characteristics of each glacier on the basis of its physical appearance and what might be deduced from it. Scientists visiting different parts of the world had tended to type glaciers according to the regions in which they were found. Terms such as Alpine, Himalayan, Scandinavian, etc. conveyed nothing of the morphological characteristics of the features in question. The guidelines proposed a classification matrix that incorporated aspects of each glacier that could be identified from maps and aerial photographs (Ommanney, 1969, table 7, p.12). This included information on the longitudinal profile and the activity of the tongue.

\section{Basic dataset}

Those items of the IGY dataset that covered the physical characteristics of each glacier were all included in the inventory guidelines. Other elements, such as accumulation, ablation and balance, were picked up by the other ICSI Working Group, chaired by Mark Meier, that produced the guidelines on glacier mass balance (UNESCO/IASH, 1970a). However, data on different parts of the glacier accumulation, ablation, debris-covered and moraine areas - were requested in consideration of inputs that might be needed for hydrological models. Because it was thought that smaller features would be more sensitive to global change, and in some areas were an important local water resource, the minimum size to be inventoried was set at 1 ha. This was also considered to be an appropriate minimum size in view of the scale of maps and aerial photographs available. Data were to be provided in fixed format for input to mainframe computers on punched cards. Trays of cards would be submitted to the computer centre to be run overnight. Today, those who have never seen a punched card, and who now have more powerful desktop machines at their fingertips than the early mainframes, may find this hard to imagine.

\section{Features for inclusion}

Because the guidelines covered ice features on and below the land, there was some debate as to the category in which rock glaciers should be placed. Based on their surface characteristics, the location in which they were expected to be found, and evidence from some areas that a few developed from more active glaciers, it was decided to include them in the surface-ice inventory. Although some of the initial IHD glacier inventories (e.g. that of Norway) excluded them, subsequent inventories have included them.
Ommanney's thesis, which describes the background to the guidelines and its application to the glaciers of Axel Heiberg Island, completed in 1968, was published in full as an Axel Heiberg Island Research Report in 1969 (Ommanney, 1969) and in part as an Inland Waters Branch Technical Bulletin. A year later, the UNESCO guide to the compilation and assemblage of data for a world inventory of perennial ice and snow masses was published (UNESCO/IASH, 1970b). It contained two pilot studies from Canada: that of the Waputik Mountains in the Canadian Rockies by A.D. Stanley, and the Steacie Ice Cap part of the Axel Heiberg Island inventory by Ommanney.

\section{DEPARTMENT OF ENERGY, MINES AND RESOURCES}

In the mid-1960s, the Geographical Branch was disbanded and all glaciological programs transferred into the Glaciology Subdivision of the Inland Waters Directorate. In 1968, Ommanney was asked to head the newly created Glacier Inventory Section. While initial work concentrated on the interpretation of aerial photographs and the delineation and identification of glaciers in the Canadian Arctic on $1: 250000$ scale maps, some resources were devoted to the headwaters area of the Prairie rivers and to Vancouver Island.

For the Axel Heiberg Island inventory, area measurements had been made on the $1: 125000$ scale advanced prints of the $1: 250000$ scale map series using a dot counter. This involved a random-dot grid where the cumulated dot count could be related to an area value. It was felt that this was not the most efficient and accurate method of assessing areas, so while scanning systems and algorithms for interpolating contours were investigated, the compilation of data was put on hold while the photographic and map interpretation and delineation proceeded apace. The first 35 glacier inventory maps of Canada in the Glacier Atlas of Canada series were published in 1969: 5 of Axel Heiberg Island, 25 of Baffin Island and 5 covering the Nelson River drainage basin. In the early 1970s, 9 maps of Devon Island, 2 of Vancouver Island and 6 of southern Ellesmere Island were published, before further work on the atlas was terminated (http://atlas.gc.ca/ site/english/maps/archives/glacier).

More detailed manuals for the preparation of the various components of the inventory were prepared (Ommanney and others, 1971; Ommanney and Clarkson, 1973) and studies undertaken into methodologies for interpreting and processing the data (Ommanney and others, 1969; Ommanney, 1972a; Ommanney and Gagnon, 1972; Wiffen, 1983; Benoît and others, 1984). As it was thought the small glaciers on Vancouver Island would be particularly susceptible to global change, a study of this area was completed and the 219 glaciers covering $27.6 \mathrm{~km}^{2}$ reported on in 1972 (Ommanney, 1972b). An inventory of Yukon glaciers was initiated through a contract with the Arctic Institute of North America in the 1970s and undertaken by Richard Ragle and Sam Collins. It involved air-photo interpretation, mapping, the delineation of individual glaciers and some basic measurements in accordance with the WGI recommendations, but did not include glacier area or volume estimates. Similar work was completed in-house for the Stikine and Iskut basins, and the watersheds lying along the west side of the Rockies in British Columbia.

Meanwhile, some universities took up the challenge of contributing to the program by taking on portions of the inventory work. Wilkins (1973) completed a study of 
glaciers in the d'Iberville Fiord area of Ellesmere Island. Whytock (1974) inventoried the ice masses of Coburg Island. Luckman and Crockett (1978) identified and classified 119 rock glaciers in Jasper National Park, confirming the accuracy of the inventory compilations and classifications previously completed in this area. Harding (1985) completed an inventory of glaciers in the Premier Range, British Columbia.

By the mid-1970s, higher-resolution satellite imagery was becoming available, so its potential application to the inventory was investigated. Barnes and Collins (1978), drawing on work already done on the Yukon inventory, investigated the potential of Landsat imagery for mapping glaciers, as did Howarth and Ommanney (1983, 1986). Barnes (1978) also used Landsat to look at Thompson Glacier, Axel Heiberg Island. Attempts at automatic classification of the imagery suggested there were still considerable problems to be overcome; mountains and low sun angle at high latitudes creating dark shadows, cloud-covered terrain, rough glacier surfaces, ice-infested marginal lakes, and debris-covered ice areas with live vegetation, all necessitated human intervention.

Progress was reported by Ommanney (1980) at the World Glacier Inventory Workshop held at Riederalp, Switzerland, in 1978.

Although no data were being published, the results available from the inventory were being used in a variety of ways. Concern on the part of the Army Survey Establishment at the ability of their cartographers to interpret some of the glaciological features correctly, when preparing the $1: 50000$ scale maps of Baffin Island, led to a request for the inventory maps to provide guidance in this area. A subset of the Arctic inventory data was provided to the Canadian Ice Service to aid in an assessment of calving glaciers and their potential threat to shipping. The inventory maps were used by the National Atlas of Canada in compiling a new base map of the glaciers of Canada (Gosson, 1985). Baranowski and Henoch (1978) and Kucera and Henoch (1978), in their study of glacier and landform features in the Columbia Icefield area, incorporated the glacier-inventory numbering system and glacier outlines in the geomorphological maps prepared for Parks Canada.

A special study of Glacier National Park, British Columbia, was commissioned by Parks Canada as part of a resource inventory. Champoux and Ommanney (1985, 1986) undertook an inventory of the glacier cover there: from the end of the Little Ice Age (LIA) reconstructed from moraine limits (assumed to be mid-1800s; based on photography in 1951/52; and also in 1978. For the latter year, the ice cover in the 15 basins measured was $193.4 \mathrm{~km}^{2}$ with an estimated volume of $11.12 \mathrm{~km}^{3}$. Subsequently, investigators from the University of Northern British Columbia have demonstrated the utility of Landsat Thematic Mapper (TM) and digital terrain modelling for measuring glaciers in this area, as well as Monkman and Parsnip Glaciers, northern Rockies (Sidjak and Wheate, 1996, 1999; Wheate and others, 2002).

\section{NATIONAL HYDROLOGY RESEARCH INSTITUTE}

The beginning of the end for the federal glacier-inventory program came with the transfer of the group, which was now part of Environment Canada, to Saskatoon. The custom-built NHRC included special quarters for housing the inventory's substantial map and photo collection. However, staff working on the inventory chose not to relocate to Saskatoon and the vacated positions were taken over to provide for administrative staff needed for the new centre. The principal investigator, Simon Ommanney, who did move, had management responsibilities that meant there was little time to continue work on the inventory. Despite this, efforts were made to continue the work and collaborate with those wishing to use the data. Clarke, and later Jiskoot, used the Yukon data to look at glaciological factors influencing glacier surging (Clarke and others, 1986; Clarke, 1991; Atkinson and others, 1998). Schmok and Hoffart (1991) were contracted to produce a customized database analysis system and Ommanney (1993) completed the inventory of the Yukon. No effort was made to replace Ommanney when he left NHRC in 1993. All inventory resources were transferred to the NHRC library and glacier-inventory activities ceased.

\section{THE MODERN ERA}

Despite the demise of the federal inventory program, many university researchers, both within Canada and outside, have taken up the challenge of determining the extent of Canada's current ice cover. The goal now is to lay the groundwork for measuring the response of glaciers to global change and assess their potential contribution to rising sea level: contributions are targeted to the Global Land Ice Measurements from Space (GLIMS) and GlobGlacier projects rather than the WGI (Raup and others, 2007; Paul and others, 2008). This is a logical consequence of the recommendations that came from the Workshop on Assessing Global Glacier Recession, held in Boulder, CO, USA, in March 2003 (Kargel and others, 2003). The work now being carried out in the Arctic and on the mainland is close to providing complete coverage of Canada's glaciers.

\section{Canadian Arctic}

A group at the University of Alberta, under Martin Sharp, has been carrying out a variety of inventory-related projects in northern Nunavut (Sharp and others, 2003). Glacier and icecap outlines in the Queen Elizabeth Islands have been mapped from Landsat 7 imagery and compared with those on the National Topographic Series (NTS) map sheets, to determine changes over a 40 year period. GLIMS inventory data for Axel Heiberg Island and southern Ellesmere Island (Sydkap Ice Cap and Manson and Prince of Wales Icefields) have been created and calving rates computed for several Ellesmere Island ice caps (Williamson and others, 2008). An inventory of surge-type glaciers has been compiled from aerial photographs and satellite imagery (Copland and others, 2003). Changes in equilibrium-line altitude from the LIA to 1960 have been reconstructed and related to climate forcing (Wolken and others, 2008a,b).

For Devon Ice Cap, areal changes and patterns of marginal retreat have been determined (Burgess and Sharp, 2004; Dowdeswell and others, 2004), changes in its thickness explored (Burgess and Sharp, 2008; Colgan and others, 2008) and iceberg fluxes computed (Burgess and others, 2005).

Further south, an inventory of Bylot Island glaciers has been completed for the GLIMS database (Dowdeswell and others, 2007), documenting changes between the late 1950s and 2000. This is part of a larger study that will include all of 
Baffin Island, parts of which are already underway (Paul and Kääb, 2005; Paul and Svoboda, 2009; Svoboda and Paul, 2009). The $1958 / 59$ data were represented by a series of digital topographic maps and digital elevation data produced from aerial photographs and provided by the Centre for Topographic Information, National Resources Canada. The 2000 datasets were derived from orthorectified Landsat 7 Enhanced TM Plus (ETM+) images: automatic classification alone proved unsatisfactory, so the datasets were modified by hand. Area calculations were made using the ERDAS IMAGINE digital-image processing suite (personal communication from E.K. Dowdeswell, 2008). Maps showing the interpretation and delineation of glaciers in Labrador had been compiled for the original inventory in the 1960s, but taken no further. Nick Barrand, at the University of Alberta, has begun preliminary work on a new inventory of Labrador glaciers and plans to look at Yukon glaciers as well (personal communication from M. Sharp, 2008).

\section{Western Canada and Yukon}

Work in western Canada is now being coordinated by the Western Canadian Cryospheric Network (WC ${ }^{2} \mathrm{~N}$; http:// wc2n.unbc.ca/), a consortium of six Canadian universities, two American universities and government and private scientists who are examining the links between climate change and glacier fluctuations (Wheate and others, 2005). Provincial maps have been collated to generate glacier areas for the mid-1980s, arriving at values of $28233 \mathrm{~km}^{2}$ for British Columbia and $1053 \mathrm{~km}^{2}$ for Alberta; analysis of Landsat TM 2005 showed reductions to 25177 and $786 \mathrm{~km}^{2}$ respectively (Menounos and others, 2007; Bolch and others, 2008; Schiefer and others, 2008a,b). Nine regions of the Cordillera are targeted for detailed analysis: north, central and south sections of the Coast and Rocky Mountains, the southern and northern Interior Ranges and the Saint Elias Mountains. Multiple historical sources will be assessed against Landsat TM, Système Probatoire pour l'Observation de la Terre (SPOT) and Advanced Spaceborne Thermal Emission and Reflection Radiometer (ASTER) scenes to determine current glacier changes and those since the LIA. Glacier changes in northwest British Columbia and adjacent Alaska have been documented by US colleagues (Larsen and others, 2007).

Independent of the $W C^{2} \mathrm{~N}$, Jiskoot and colleagues have been working on inventories and analysis of the Clemenceau and Chaba Icefield groups (Jiskoot and Curran, 2008), as well as on the tributary-trunk interaction of Yukon glaciers (Kargel and others, 2005; Darling and Jiskoot, 2007), based on previous inventory data. Dixon (2006) has looked at glaciers in the Selwyn and Mackenzie Mountains, Yukon and Northwest Territories. Evans has been undertaking inventory-related work in the Bendor and Shulaps Ranges for several time periods. The study is not to WGI specifications, but focuses on aspect, altitude and change analysis. It follows on his previous work with British Columbia and Yukon data (Evans, 1990, 2004, 2006; Evans and Cox, 2005). Most recently, VanLooy and Forster (2008) have contributed a study of five icefields in southwest British Columbia.

\section{CONCLUSION}

To round out the present review, mention should also be made of the Satellite Image Atlas of Glaciers of the World project of the US Geological Survey. In 2002, the volume covering Canada was published (Williams and Ferrigno, 2002). Although this does not add to the dataset on Canadian glaciers, it does provide a comprehensive description of many of Canada's glacierized areas, and information on many sources of further information.

It is rather unlikely there will now be a complete inventory of Canadian glaciers in accordance with the original WGI recommendations. However, the objective of that program, to document the extent and characteristics of the world's perennial snow and ice masses, should be met shortly in Canada by those contributing to the GLIMS and GlobGlacier programs. Indeed, the emphasis on global change means that we will not just have a snapshot for one point in time, but the extent and changes of the ice cover for various times since the LIA will also be documented. However, it would be gratifying if more use could be made of the substantial information already on file with Environment Canada. Once the question of rising sea level has been settled, it may be time to turn the inventory back to its original objective and apply it to documenting issues related to declining water resources, likely to be of particular concern in western Canada.

\section{ACKNOWLEDGEMENTS}

The author would like to thank E. Dowdeswell, I. Evans, H. Jiskoot, B. Menounos, F. Paul and M. Sharp for their contributions to the section on the modern era.

\section{REFERENCES}

Annals of the International Geophysical Year. 1959. IX. Glaciology. Ann. IGY, 8, Parts I, II and III, 289-292.

Atkinson, P., H. Jiskoot, R. Massari and T. Murray. 1998. Generalized linear modelling in geomorphology. Earth Surf. Process. Landf., 23(13), 1185-1195.

Baranowski, S. and W.E.S. Henoch. 1978. Glacier and landform features in the Columbia Icefields area, Banff and Jasper National Parks, Alberta, Canada. Ottawa, Ont., Environment Canada. Inland Waters Directorate.

Barnes, R.B. 1978. The application of the UNORSAL software system to LANDSAT digital data: the Thompson Glacier of Axel Heiberg Island, N.W.T., Canada. In Rundquist, D.C., ed. The use of LANDSAT digital information for assessing glacier inventory parameters: an evaluation. Omaha, NE, University of Nebraska at Omaha. Remote Sensing Applications Laboratory, 118-133.

Barnes, R.B. and S.G. Collins. 1978. Glacier mapping from LANDSAT digital data, St. Elias Mts., Yukon, Canada. In Rundquist, D.C., ed. The use of LANDSAT digital information for assessing glacier inventory parameters: an evaluation. Omaha, NE, University of Nebraska at Omaha. Remote Sensing Applications Laboratory, 41-73.

Benoît, I., A. Champoux, C.S.L. Ommanney and J.-M.M. Dubois. 1984. Clef pour la photo-interprétation des glaciers tempérés (le glacier Athabasca, Canada). Photo Interp. 84-4, 29-32.

Bolch, T., B. Menounos and R. Wheate. 2008. Remotely-sensed western Canadian glacier inventory 1985-2005 and regional glacier recession rates. Geophys. Res. Abstr., 10, EGU2008-A10403.

Burgess, D.O. and M.J. Sharp. 2004. Recent changes in areal extent of the Devon ice cap, Nunavut, Canada. Arct. Antarct. Alp. Res., 36(2), 261-271.

Burgess, D. and M.J. Sharp. 2008. Recent changes in thickness of the Devon Island ice cap, Canada. J. Geophys. Res., 113(B7), B07204. (10.1029/2007JB005238.) 
Burgess, D.O., M.J. Sharp, D.W.F. Mair, J.A. Dowdeswell and T.J. Benham. 2005. Flow dynamics and iceberg calving rates of Devon Ice Cap, Nunavut, Canada. J. Glaciol., 51(173), 219-230.

Champoux, A. and C.S.L. Ommanney. 1985. Repartition spatiale, évolution et caractéristiques des glaciers du Parc national de Glacier, Colombie-Britannique. Ottawa, Ont., Environnement Canada. Institut national de recherches en hydrologie. Direction générale des eaux intérieures. (Rapport interne.)

Champoux, A. and C.S.L. Ommanney. 1986. Photo-interpretation, digital mapping, and the evolution of glaciers in Glacier National Park, B.C. Ann. Glaciol., 8, 27-30.

Clarke, G.K.C. 1991. Length, width and slope influences on glacier surging. J. Glaciol., 37(126), 236-246.

Clarke, G.K.C., J.P. Schmok, C.S.L. Ommanney and S.G. Collins. 1986. Characteristics of surge-type glaciers. J. Geophys. Res., 91(B7), 7165-7180.

Cogley, J.G. 2009. A more complete version of the World Glacier Inventory. Ann. Glaciol., 50(53) (see paper in this issue).

Colgan, W., J. Davis and M. Sharp. 2008. Is the high-elevation region of Devon Ice Cap thickening? J. Glaciol., 54(186), 428-436.

Copland, L., M.J. Sharp and J.A. Dowdeswell. 2003. The distribution and flow characteristics of surge-type glaciers in the Canadian High Arctic. Ann. Glaciol., 36, 73-81.

Darling, S. and H. Jiskoot. 2007. Tributary-trunk glacier interaction classification in the St Elias Mountains, Yukon Territory, from satellite imagery. In Annual Meeting, Western Division of the Canadian Association of Geographers, 8-10 March 2007, University College of the Fraser Valley, Abbotsford, British Columbia. Program and abstracts. Abbotsford, B.C., Canadian Association of Geographers. Western Division, 23-24.

Dixon, J.D. 2006. Estimating and mapping the equilibrium line elevations of glaciers in the Selwyn and Mackenzie Mountains, Yukon and Northwest Territories, using the Kurowski method. (BSc thesis, Trent University.)

Dowdeswell, J.A., T.J. Benham, M.R. Gorman, D. Burgess and M. Sharp. 2004. Form and flow of the Devon Island ice cap, Canadian Arctic. J. Geophys. Res., 109(F2), F02002. (10.1029/ 2003JF000095.)

Dowdeswell, E.K., J.A. Dowdeswell and F. Cawkwell. 2007. On the glaciers of Bylot Island, Nunavut, Arctic Canada. Arct. Antarct. Alp. Res., 39(3), 402-411.

Evans, I.S. 1990. Climatic effects on glacier distribution across the southern Coast Mountains, B.C., Canada. Ann. Glaciol., 14, $58-64$.

Evans, I.S. 2004. Twentieth-century change in glaciers of the Bendor and Shulaps Ranges, British Columbia Coast Mountains. Quat. Newsl. 104, 70-72.

Evans, I.S. 2006. Local aspect asymmetry of mountain glaciation: a global survey of consistency of favoured directions for glacier numbers and altitudes. Geomorphology, 73(1-2), 166-184.

Evans, I.S. and N.J. Cox. 2005. Global variations of local asymmetry in glacier altitude: separation of north-south and east-west components. J. Glaciol., 51(174), 469-482.

Falconer, G. 1962. Glaciers of northern Baffin Island and Bylot Islands, N.W.T. Ottawa, Ont., Department of Mines and Technical Surveys. Geographical Branch. (Geographical Paper 33.)

Falconer, G., J. Falconer and R. Kellerhals. 1958. Inventory of Canadian Glaciers: preliminary measurements - Arctic Canada. Vol. Part I. Arctic Archipelago. Toronto, Ont., University of Toronto. Department of Geography. (Unpublished manuscript.)

Gosson, C.M.C. 1985. Canada - glaciers. Fifth edition. (Scale: $1: 7,500,000$.$) Ottawa, Ont., Energy, Mines and Resources$ Canada, Surveys and Mapping Branch. Geographical Services Division. (National Atlas of Canada map MCR-4080.)

Harding, K.A. 1985. Glacier inventory of the Premier Range, British Columbia. (BSc thesis, University of Western Ontario.)

Howarth, P.J. and C.S.L. Ommanney. 1983. LANDSAT digital data for updating glaciological information on topographic and glacier inventory maps. In Wellar, B.S., ed. Automated cartography: international perspectives on achievements and challenges. Proceedings of the Sixth International Symposium on Automated Cartography, 16-21 October 1983, National Capital Region of Canada, Vol. II. Ottawa, Ont., Steering Committee for the Sixth International Symposium on Automated Cartography, 504-513.

Howarth, P.J. and C.S.L. Ommanney. 1986. The use of Landsat digital data for glacier inventories. Ann. Glaciol., 8, 90-92.

International Union of Geodesy and Geophysics (IUGG). 1956. Resolutions on glaciology and climatology. IUGG News Lett., 5(13), 43.

Jiskoot, H. and C. Curran. 2008. Calculating glacier change in the Clemenceau Icefield Group, Canadian Rocky Mountains. In Proceedings of the 34th Annual Meeting of the Canadian Geophysical Union, 11-14 May 2008, Banff, Alberta. Program and Abstracts. Calgary, Alta., Canadian Geophysical Union, 95.

Kargel, J. and 9 others. 2003. Working Group 2: world glacier inventories. Glaciol. Data, GD-32 World Data Center A for Glaciology <Snow and Ice>, Boulder, CO, 41-43.

Kargel, J.S. and 16 others. 2005. Multispectral imaging contributions to global land ice measurements from space. Remote Sens. Environ., 99(1-2), 187-219.

Kucera, R.E. and W.E.S. Henoch. 1978. Glacier and landform features in the Columbia Icefield area, Banff and Jasper National Parks, Alberta, Canada. Ottawa, Ont., Environment Canada, Inland Waters Directorate.

Larsen, C.F., R.J. Motyka, A.A. Arendt, K.A. Echelmeyer and P.E. Geissler. 2007. Glacier changes in southeast Alaska and northwest British Columbia and contribution to sea level rise. J. Geophys. Res., 112(F1), F01007. (10.1029/2006JF000586.)

Luckman, B.H. and K.J. Crockett. 1978. Distribution and characteristics of rock glaciers in the southern part of Jasper National Park, Alberta. Can. J. Earth Sci., 15(4), 540-550.

Menounos, B., T. Bolch, M. Beedle, R. Wheate, S. Amanda and C. Tennant. 2007. First results from a satellite and photo-based glacier inventory for British Columbia, Canada. [Abstr. C12A08.] Eos, 88(52), Fall Meet. Suppl.

Ommanney, C.S.L. 1969. A study in glacier inventory: the ice masses of Axel Heiberg Island, Canadian Arctic Archipelago. Montréal, Que., McGill University. (Axel Heiberg Island Research Reports Glaciology 3.)

Ommanney, C.S.L. 1971. The Canadian glacier inventory. In Glaciers, Proceedings of Workshop Seminar 1970, 24-25 September 1970, Vancouver, B.C. Ottawa, Ont., Canadian National Committee for the International Hydrological Decade, 23-30.

Ommanney, C.S.L. 1972a. Acquisition, storage, and processing of glacier inventory data. In Computer storing and processing of hydrological data. Proceedings of Workshop Seminar 1971, 19-20 October 1971, Quebec City, Quebec. Ottawa, Ont., Canadian National Committee for the International Hydrological Decade, 27-29.

Ommanney, C.S.L. 1972b. Application of the Canadian glacier inventory to studies of the static water balance. 1. The glaciers of Vancouver Island. In Adams, W.P. and F.M. Helleiner, eds. International geography 1972, Vol. 2. Toronto, Ont., University of Toronto Press, 1266-1268.

Ommaney, C.S.L. 1978. New basin numbering - Glacier inventory of Canada: tentative designations to conform with IDENTIFICATION/GLACIER NUMBER supplement issued by the Temporary Technical Secretariat for World Glacier Inventory. Ottawa, Ont., Environment Canada. Glaciology Division. (Unpublished report.)

Ommanney, C.S.L. 1980. The inventory of Canadian glaciers: procedures, techniques, progress and applications. IAHS Publ. 126 (Workshop at Riederalp 1978 - World Glacier Inventory), $35-44$.

Ommanney, C.S.L. 1993. Yukon glaciers. In Prowse, T.D., C.S.L. Ommanney and K.E. Ulmer, eds. Proceedings of the 9th International Northern Research Basins Symposium/Workshop, 14-22 August 1992, Vol. 1. Saskatoon, Sask., Environment 
Canada. National Hydrology Research Institute, 373-382. (NHRI Symposium 10.)

Ommanney, C.S.L. 2002. Mapping Canada's glaciers. In Williams, R.S., Jr and J.G. Ferrigno, eds. Glaciers of North America. Satellite image atlas of glaciers of the world. Denver, CO, United States Geological Survey, J83-J110. (USGS Professional Paper 1386-J.)

Ommanney, C.S.L. and J.W. Clarkson. 1973. Information booklet for ICEREF, the bibliography of Canadian glaciers. Ottawa, Ont., Department of the Environment. Inland Waters Directorate. (IWD Report Series 27.)

Ommanney, C.S.L. and D. Gagnon. 1972. Data acquisition and presentation for the glacier inventory of Canada. In Adams, W.P. and F.M. Helleiner, eds. International geography 1972, Vol. 2. Toronto, Ont., University of Toronto Press, 980-982.

Ommanney, C.S.L., R.H. Goodman and F. Müller. 1969. Computer analysis of a glacier inventory of Axel Heiberg Island, Canadian Arctic Archipelago. IASH Bull., 14(1), 19-28.

Ommanney, C.S.L., J. Clarkson and M.M. Strome. 1971. Information booklet for the inventory of Canadian glaciers. Ottawa, Ont., Energy, Mines and Resources Canada. Inland Waters Branch. (Glacier Inventory Note 4.)

Paul, F. and A. Kääb. 2005. Perspectives on the production of a glacier inventory from multispectral satellite data in Arctic Canada: Cumberland Peninsula, Baffin Island. Ann. Glaciol., 42, 59-66.

Paul, F. and F. Svoboda. 2009. A new glacier inventory on southern Baffin Island, Canada, from ASTER data: II. Data analysis, glacier change and applications. Ann. Glaciol., 50(53) (see paper in this issue).

Paul, F., A. Kääb, H. Rott, A. Shepherd and T. Strozzi. 2008. GlobGlacier: a new ESA project to map the world's glaciers from space. Geophys. Res. Abstr., 10, EGU2008-A-10444.)

Raup, B., A. Racoviteanu, S.J.S. Khalsa, C. Helm, R. Armstrong and Y. Arnaud. 2007. The GLIMS geospatial glacier database: a new tool for studying glacier change. Global Planet. Change, 56(1-2), 101-110.

Roberts, B.B. 1963. Universal decimal classification for use in polar libraries. Cambridge, Scott Polar Research Institute. (Occasional Paper 2.)

Schiefer, E., B. Menounos and R. Wheate. 2007. Recent volume loss of British Columbian glaciers, Canada. Geophys. Res. Lett., 34(16), L16503. (10.1029/2007GL030780.)

Schiefer, E., B. Menounos and R. Wheate. 2008. An inventory and morphometric analysis of British Columbia glaciers, Canada. J. Glaciol., 54(186), 551-560.

Schmok, J.P. and D.G. Hoffart. 1991. Development of the Glacier Database Inventory System: custom database program. Saskatoon, Sask., Environment Canada. National Hydrology Research Institute.

Sharp, M., L. Copland, K. Filbert, D. Burgess and S. Williamson. 2003. Recent changes in the extent and volume of Canadian Arctic glaciers. Glaciol. Data, GD-32 World Data Center A for Glaciology. <Snow and Ice>, Boulder, CO 70-72.

Sidjak, R.W. and R.D. Wheate. 1996. Glacier mapping and inventory of the Illecillewaet River basin, British Columbia, Canada, using LANDSAT TM and digital elevation data. In Guyenne, T.D., ed. Proceedings of the Fourth Circumpolar Symposium on Remote Sensing of the Polar Environments, 29 April-1 May 1996, Lyngby, Denmark. Noordwijk, European Space Agency, 47-51. (ESA Special Publication SP-391.)
Sidjak, R.W. and R.D. Wheate. 1999. Glacier mapping of the Illecillewaet icefield, British Columbia, Canada, using Landsat TM and digital elevation data. Int. J. Remote Sens., 20(2), 273-284.

Svoboda, F. and F. Paul. 2009. A new glacier inventory on southern Baffin Island, Canada, from ASTER data: I. Applied methods, challenges and solutions. Ann. Glaciol., 50(53) (see paper in this issue).

UNESCO. 1964. International Hydrological Decade Intergovernmental Meeting of Experts, Paris, April 7-17, 1964: final report. Paris, UNESCO. (UNESCO/NS/188.)

UNESCO/International Association of Scientific Hydrology (IASH). 1970a. Combined heat, ice and water balances at selected glacier basins: a guide for compilation and assemblage of data for glacier mass balance measurements. Paris, UNESCO/IASH. (Technical Papers in Hydrology 5.)

UNESCO/IASH. 1970b. Perennial ice and snow masses: a guide for compilation and assemblage of data for a world inventory. Paris, UNESCO/IASH. (Technical Papers in Hydrology 1.)

VanLooy, J.A. and R.R. Forster. 2008. Glacial changes of five southwest British Columbia icefields, Canada, mid-1980s to 1999. J. Glaciol., 54(186), 469-478.

Wheate, R.D., R.W. Sidjak and G.T. Whyte. 2002. Mapping glaciers in the Interior Ranges and Rocky Mountains with Landsat data. In Williams, R.S., Jr and J.G. Ferrigno, eds. Glaciers of North America. Satellite image atlas of glaciers of the world. Denver, CO, United States Geological Survey, J-100-J-105. (USGS Professional Paper 1386-J.)

Wheate, R., V. Lindsay, N. Alexander and B. Menounos. 2005. Glacier extent changes in northern, central and southern British Columbia using Landsat Thematic Mapper, digital elevation models and historic map vectors. In 31st Annual Meeting of the Canadian Geophysical Union, 8-11 May 2005, Banff, Alberta. Program and abstracts. Calgary, Alta., Canadian Geophysical Union. (Abstract 178.) CD-ROM.

Whytock, J.K. 1974. An inventory of the perennial ice masses of Coburg Island, N.W.T.: a case study of glacier inventory research techniques. (MA thesis, Carleton University.)

Wiffen, S.W. 1983. A procedure manual for digitizing the Glacier Inventory Project. Waterloo, Ont., University of Waterloo. Department of Geography. Unpublished report prepared for Professor L. Guelke. (Co-op Geography 4A, Work Terms Number 4 and 5, 19 September.)

Wilkins, S.P. 1973. Some glaciological problems involved in glacier inventory: a case study, d'Iberville Fiord, Ellesmere Island, N.W.T. (BA thesis, McMaster University.)

Williams, R.S., Jr and J.G. Ferrigno, eds. 2002. Glaciers of North America. Satellite image atlas of glaciers of the world. Washington, DC, US Geological Survey. (USGS Professional Paper 1386-J.)

Williamson, S., M. Sharp, J. Dowdeswell and T. Benham. 2008. Iceberg calving rates from northern Ellesmere Island ice caps, Canadian Arctic, 1999-2003. J. Glaciol., 54(186), 391-400.

Wolken, G.J., M.J. Sharp and J.H. England. 2008a. Changes in lateNeoglacial climate inferred from former equilibrium-line altitudes in the Queen Elizabeth Islands, Arctic Canada. Holocene, 18(4), 629-641.

Wolken, G.J., J.H. England and A.S. Dyke. 2008b. Changes in late Neoglacial perennial snow/ice extent and equilibrium-line altitudes in the Queen Elizabeth Islands, Arctic Canada. Holocene, 18(4), 615-627. 